\title{
Landscape controls on riverine export of dissolved organic carbon from Great Britain
}

\author{
Jennifer L. Williamson • Andrew Tye • Dan J. Lapworth · Don Monteith • \\ Richard Sanders · Daniel J. Mayor · Chris Barry • Mike Bowes • \\ Michael Bowes • Annette Burden • Nathan Callaghan • Gareth Farr • \\ Stacey Felgate - Alice Fitch - Stuart Gibb • Pete Gilbert • Geoff Hargreaves • \\ Patrick Keenan • Vassilis Kitidis • Monika Juergens • Adrian Martin • \\ Ian Mounteney $\cdot$ Philip D. Nightingale $\cdot$ M. Gloria Pereira $\cdot$ Justyna Olszewska • \\ Amy Pickard • Andrew P. Rees • Bryan Spears • Mark Stinchcombe • \\ Debbie White $\cdot$ Peter Williams $\cdot$ Fred Worrall $\cdot$ Chris Evans
}

Received: 21 April 2020/ Accepted: 22 January 2021

(C) The Author(s) 2021

\begin{abstract}
The dissolved organic carbon (DOC) export from land to ocean via rivers is a significant term in the global $\mathrm{C}$ cycle, and has been modified in many areas by human activity. DOC exports from large global rivers are fairly well quantified, but those from smaller river systems, including those draining oceanic regions, are generally under-represented in
\end{abstract}

Responsible Editor: Penny Johnes.

J. L. Williamson $(\bowtie) \cdot$ C. Barry · A. Burden .

N. Callaghan · A. Fitch · C. Evans

UK Centre for Ecology \& Hydrology, Environment

Centre Wales, Deiniol Road, Bangor LL57 2UW,

Gwynedd, UK

e-mail: jwl@ceh.ac.uk

A. Tye $\cdot$ M. Bowes - I. Mounteney

British Geological Survey, Keyworth,

Nottingham NG12 5GG, UK

D. J. Lapworth · D. White · P. Williams

British Geological Survey, Maclean Building,

Wallingford OX10 8BB, UK

D. Monteith · P. Keenan - M. G. Pereira

UK Centre for Ecology \& Hydrology, Lancaster

Environment Centre, Library Avenue,

Bailrigg, Lancaster LA1 4AP, UK global syntheses. Given that these regions typically have high runoff and high peat cover, they may exert a disproportionate influence on the global land-ocean DOC export. Here we describe a comprehensive new assessment of the annual riverine DOC export to estuaries across the island of Great Britain (GB), which spans the latitude range $50-60^{\circ} \mathrm{N}$ with strong spatial gradients of topography, soils, rainfall, land use and population density. DOC yields (export per unit

R. Sanders - D. J. Mayor - S. Felgate .

A. Martin - M. Stinchcombe

National Oceanography Centre, European Way,

Southampton SO14 3ZH, UK

Present Address:

R. Sanders

NORCE Norwegian Research Centre, Janhnebakken 5, 5007 Bergen, Norway

M. Bowes · M. Juergens

UK Centre for Ecology \& Hydrology, Maclean Building,

Wallingford OX10 8BB, UK

G. Farr

British Geological Survey, Cardiff University, Main

Building, Park Place, Cardiff CF10 3AT, UK

S. Gibb · P. Gilbert

University of the Highlands and Islands, Environmental Research Institute, Castle Street, Thurso KW14 7JD, UK 
area) were positively related to and best predicted by rainfall, peat extent and forest cover, but relatively insensitive to population density or agricultural development. Based on an empirical relationship with land use and rainfall we estimate that the DOC export from the GB land area to the freshwater-seawater interface was $1.15 \mathrm{Tg} \mathrm{C}_{\text {year }}{ }^{-1}$ in 2017 . The average yield for GB rivers is $5.04 \mathrm{~g} \mathrm{C} \mathrm{m}^{-2}$ year $^{-1}$, higher than most of the world's major rivers, including those of the humid tropics and Arctic, supporting the conclusion that under-representation of smaller river systems draining peat-rich areas could lead to under-estimation of the global land-ocean DOC export. The main anthropogenic factor influencing the spatial distribution of GB DOC exports appears to be upland conifer plantation forestry, which is estimated to have raised the overall DOC export by $0.168 \mathrm{Tg} \mathrm{C}$ year $^{-1}$. This is equivalent to $15 \%$ of the estimated current rate of net $\mathrm{CO}_{2}$ uptake by British forests. With the UK and many other countries seeking to expand plantation forest cover for climate change mitigation, this 'leak in the ecosystem' should be incorporated in future assessments of the $\mathrm{CO}_{2}$ sequestration potential of forest planting strategies.

Keywords Dissolved organic carbon - Great britain . Rivers - DOC export - DOC yield - Terrigenous DOC

\section{Introduction}

The Intergovernmental Panel on Climate Change (IPCC) estimates that the global export flux of carbon (C) from the terrestrial biosphere to rivers is $1.7 \mathrm{Pg} \mathrm{C}$

\section{G. Hargreaves}

National Oceanography Centre, Joseph Proudman Building, 6 Brownlow Street, Liverpool L3 5DA, UK

V. Kitidis · P. D. Nightingale · A. P. Rees Plymouth Marine Laboratory, Prospect Place, The Hoe, Plymouth PL1 3DH, UK

\section{J. Olszewska $\cdot$ A. Pickard $\cdot$ B. Spears}

UK Centre for Ecology \& Hydrology, Bush Estate, Penicuik, Midlothian EH26 0QB, Scotland, UK

\section{F. Worrall}

Department of Earth Sciences, Durham University, Durham DH1 3LE, UK year $^{-1}$ (Ciais et al. 2013). This export, which comprises dissolved and particulate organic and inorganic carbon, is equal to the net pre-industrial uptake of atmospheric $\mathrm{CO}_{2}$ by the terrestrial biosphere, and similar in magnitude to the present-day net uptake of atmospheric $\mathrm{CO}_{2}$ by the oceans. Approximately half of this $\mathrm{C}$ was estimated by the IPCC to be either outgassed from freshwaters as $\mathrm{CO}_{2}$ or buried in freshwater sediments, leaving an estimated $0.9 \mathrm{Pg} \mathrm{C}$ year ${ }^{-1}$ to be exported to the ocean. Of this river-toocean $\mathrm{C}$ export, some is buried in marine sediments or outgassed, some enters the $700 \mathrm{Pg}$ marine dissolved organic carbon (DOC) pool, and the remainder enters the $38,000 \mathrm{Pg}$ oceanic dissolved inorganic carbon (DIC) pool (Ciais et al. 2013).

While there is considerable uncertainty over the size of these pools and exports, Drake et al. (2018) suggested that the river to ocean $\mathrm{C}$ flux, and thus the DOC component of this export, are relatively well quantified, with a low uncertainty. Over time the number of rivers used to estimate the land-ocean DOC export has gradually increased, from less than 40 to more than 250 (Cauwet 2002; Dai et al. 2012; Li et al. 2017; Ludwig et al. 1996; Meybeck 1982), but the export estimate has remained fairly stable at between 0.20 and $0.24 \mathrm{Pg} \mathrm{C}_{\mathrm{year}}{ }^{-1}$. To some extent, this could reflect common data sources, and a general focus on the larger river systems that generate the majority of global river discharge (Raymond and Spencer 2015). Taking a different approach of aggregating data by biome and predicting fluxes based on soil properties, Aitkenhead and McDowell (2000) used a dataset of 164 rivers to obtain a higher DOC export estimate of $0.36 \mathrm{Pg} \mathrm{C}$ year $^{-1}$. However, by including many small headwater catchments, they may have over-estimated the land-ocean export by not accounting for DOC removal processes within the freshwater drainage network. While the land-ocean DOC export does appear to be relatively well-constrained, the dominance of larger rivers in most calculations could introduce a negative bias if under-represented smaller river systems have higher average DOC yields (flux per unit area). This could indeed be the case because peatlands, which generate the highest DOC yields, often form in near-coastal areas and drain via smaller rivers; for example none of the thirty largest global rivers by flow analysed by Raymond and Spencer (2015) drain the comparatively peat-rich regions of Northwest Europe, the Hudson Bay Lowlands, 
Indonesia, or Patagonia. Moore et al. (2013) measured DOC yields from an Indonesian blackwater river around 30 times higher than the global large river mean calculated by Raymond and Spencer (2015), suggesting the potential for such areas to contribute significantly to global riverine DOC fluxes despite comparatively small river flows. There is, therefore, a need both for more comprehensive riverine flux data from different geographic regions, including peat-rich temperate and boreal regions, and for an improved understanding of the relationships between riverine $\mathrm{C}$ fluxes and catchment properties within these geographic regions.

Greater knowledge of the controls on riverine $\mathrm{C}$ exports is also important in the context of global environmental change; a large component of the dissolved organic and inorganic $\mathrm{C}$ export from soils to rivers is natural, and thus an intrinsic component of the Earth's C cycle. However, human activities such as agriculture, urbanisation and changes to drainage systems have increased the fluxes of both DIC (Raymond et al. 2008) and DOC (Moore et al. 2011), via organic matter oxidation and weathering. This weathering has re-introduced 'old' C previously isolated from the hydrological cycle into circulation (Butman et al. 2015). Regnier et al. (2013) estimate that human activities have led to an increase in $\mathrm{C}$ export from soils to rivers of up to $1 \mathrm{Pg} \mathrm{C}$ year $^{-1}$, of which approximately $80 \%$ is soil derived, and most is in organic forms, although they further suggest that around $90 \%$ of this increase is either outgassed or buried in sediments, with only a small change in $\mathrm{C}$ input to the ocean. On average, DOC makes up around $25-50 \%$ of riverine $\mathrm{C}$ inputs to the oceans, depending on geographic region (Ciais et al. 2008; Cole et al. 2007; Drake et al. 2018; Huang et al. 2012), and will be the focus of this work because it likely represents the most biogeochemically active component of the total export.

Previous studies have shown that the primary controls on spatial variation in the DOC export from soils to rivers include soil type and vegetation cover (Aitkenhead and McDowell 2000; Hope et al. 1997). Organic (peat) soils occupy around 3\% of the land surface, yet contain one third to a half of all soil organic carbon (Nichols and Peteet 2019; Yu 2012) and generate the highest riverine DOC yields (i.e. export per unit area) (Aitkenhead and McDowell 2000). Agricultural soils, by contrast, occupy $33 \%$ of the land surface and have varying, but typically much lower, levels of organic carbon (Scharlemann et al. 2014) and DOC export. The biochemical characteristics of organic matter exported from these ecosystems are fundamentally different. Peatlands produce high $\mathrm{C}: \mathrm{N}$, biologically refractory, photochemically reactive DOC, whereas agricultural land produces low C:N, biologically labile, photochemically resistant DOC (Berggren and del Giorgio 2015; Jones et al. 2016; Yates et al. 2016).

Great Britain (GB, comprising the countries of Scotland, England and Wales) is the world's $9^{\text {th }}$ largest island, and forms a hydrologically discrete study unit of many small (by global standards) river systems which drain a highly diverse range of topography, soils and land-use. Together with a wealth of existing data, this makes it a good location to assess the large scale driving variables affecting organic matter fluxes in fluvial systems within the temperate zone. Great Britain also has a relatively large coverage of deep peat organic soils (12\%), primarily blanket bog ecosystems, in the northern and western uplands of Scotland, Northern England and Wales (Evans et al. 2017a). There is a strong geographic gradient in soil C content, meteorology and land-use, with the lowland mineral soils of Southern and Eastern England largely converted to agricultural use (arable and improved grassland), and having a low C content. Overall, approximately $50 \%$ of the GB land surface is covered by arable and improved grassland (Rowland et al. 2017). We use data from a coordinated, GB-wide oneyear sampling campaign aimed at estimating the total flux and composition of riverine DOC export from the GB land mass. For the purposes of this study (and in common with most previous studies of riverine DOC export) we defined the boundary for terrestrial to marine DOC export as the lower limit of freshwater; i.e. we did not account for DOC removal (or production) processes within the estuary, which will be considered in a follow-up paper (Garcia-Martin et al. in prep.). However, we did attempt to account for DOC export from unsampled catchments and land areas draining directly to estuaries. Our sampling programme directly measured export from a large proportion of the total GB land area (36\%) and captured the entire range of soils and land-cover. To our knowledge, this represents the most comprehensive, coordinated survey of land-ocean DOC fluxes to have been undertaken in GB based on directly 
measured DOC rather than absorbance based proxies. We report our analysis of the spatial controls on fluvial DOC yields and provide a new estimate of whole GB DOC export flux based on a catchment scale model using these variables.

\section{Methods}

River sampling

Forty rivers draining $36 \%$ of the GB land mass (Fig. 1) were sampled in the third week of each month during 2017. They were sampled close to the tidal limit, and where possible at long-term national hydrometric and water quality monitoring sites. Where existing discharge and water quality monitoring sites did not coincide, sampling was conducted at the long-term water quality monitoring sites unless it was unsafe to access this site. Water samples were filtered immediately through $0.45 \mu \mathrm{m}$ cellulose acetate filters using rubber free syringes into HDPE bottles for DOC analysis and amber glass bottles for UV absorbance measurements. Samples were posted to the laboratory under cool conditions within $24 \mathrm{~h}$ of collection.

\section{Sample analysis}

A Shimadzu TOC-L analyser was used to measure DOC in filtered samples. Prior to analysis samples were acidified with $1 \mathrm{M} \mathrm{HCl}$ then purged with Zero grade air for 6 min to remove any inorganic carbon. The sample was then analysed for the remaining carbon, measured by combustion at $720{ }^{\circ} \mathrm{C}$ with a catalyst, which converts all carbon to carbon dioxide. The carbon dioxide is measured using an infra-red detector.

Specific UV absorbance at $254 \mathrm{~nm}\left(\mathrm{SUVA}_{254}\right)$ was measured using a Cary Eclipse $60 \mathrm{UV}-\mathrm{Vis}$ spectrometer, a $1 \mathrm{~cm}$ quartz cuvette, and Milli-Q water as a baseline reference. All analysis was undertaken within 10 days of sampling and samples were refrigerated prior to analysis. $\mathrm{SUVA}_{254}$ gives an indication of the aromaticity of the DOC pool (Weishaar et al. 2003), and hence an indication of DOC origin and reactivity. SUVA $_{254}$ is calculated as the absorbance (A) at $254 \mathrm{~nm}$ normalised to a $1 \mathrm{~m}$ path length (1) divided by the DOC concentration in $\mathrm{mg} \mathrm{L}^{-1}$ (Eq. 1) (e.g. Painter et al. 2018; Weishaar et al. 2003).
Fig. 1 location of catchment monitoring during 2017 showing surface water catchment boundaries for each sample point. Peat soils are shown in brown and the major watersheds determining flow into the different sea areas shown are represented by thick black lines

$S U V A_{254}=\frac{\frac{A}{l}}{D O C}$

DOC flux calculation

Mean daily water flows from the 40 rivers monitored during 2017 were obtained from the national agencies for England, Scotland and Wales (Environment Agency (EA), Scottish Environmental Protection Agency (SEPA) and Natural Resources Wales (NRW), respectively). For three rivers (Mersey, Eden and Welsh Dee) co-located flow data were not available during 2017 so upstream discharge gauging data were used to estimate flows at the sample location. The relationship between upstream and downstream daily flows during 2015, the most recent year with comparable data, was calculated using regression analysis and daily flows for the sampling site for 2017 were estimated from the regression equation. Past annual discharge volumes were calculated for each comparison gauging station to ensure that total annual discharge was within $10 \%$ at each site, with a correction made to the annual discharge calculation for 2017 if differences between upstream and downstream gauging stations were greater than 10\%. Flow data for 2017 were unavailable for the Beauly so DOC fluxes were calculated based on flows measured on the Conon, the adjacent river with similar catchment area, assuming the same mean areal runoff for both (topographically similar) catchments. Flow data for 2017 were unavailable for the Dyfi, so this was excluded from the DOC flux data analysis.

Annual DOC river fluxes were calculated using "method 5" of Littlewood et al. (1998), detailed in Eq. 2, where $\mathrm{k}$ specifies a conversion factor for the duration of sampling (in this case 1 year), $C_{i}$ refers to the DOC concentration at sampling time $\mathrm{i}, \mathrm{Q}_{\mathrm{i}}$ refers to flow at sampling time $\mathrm{i}, \mathrm{Q}_{\mathrm{T}}$ refers to the mean flow over the whole sampling period, and $\mathrm{n}$ is the number of samples taken. 


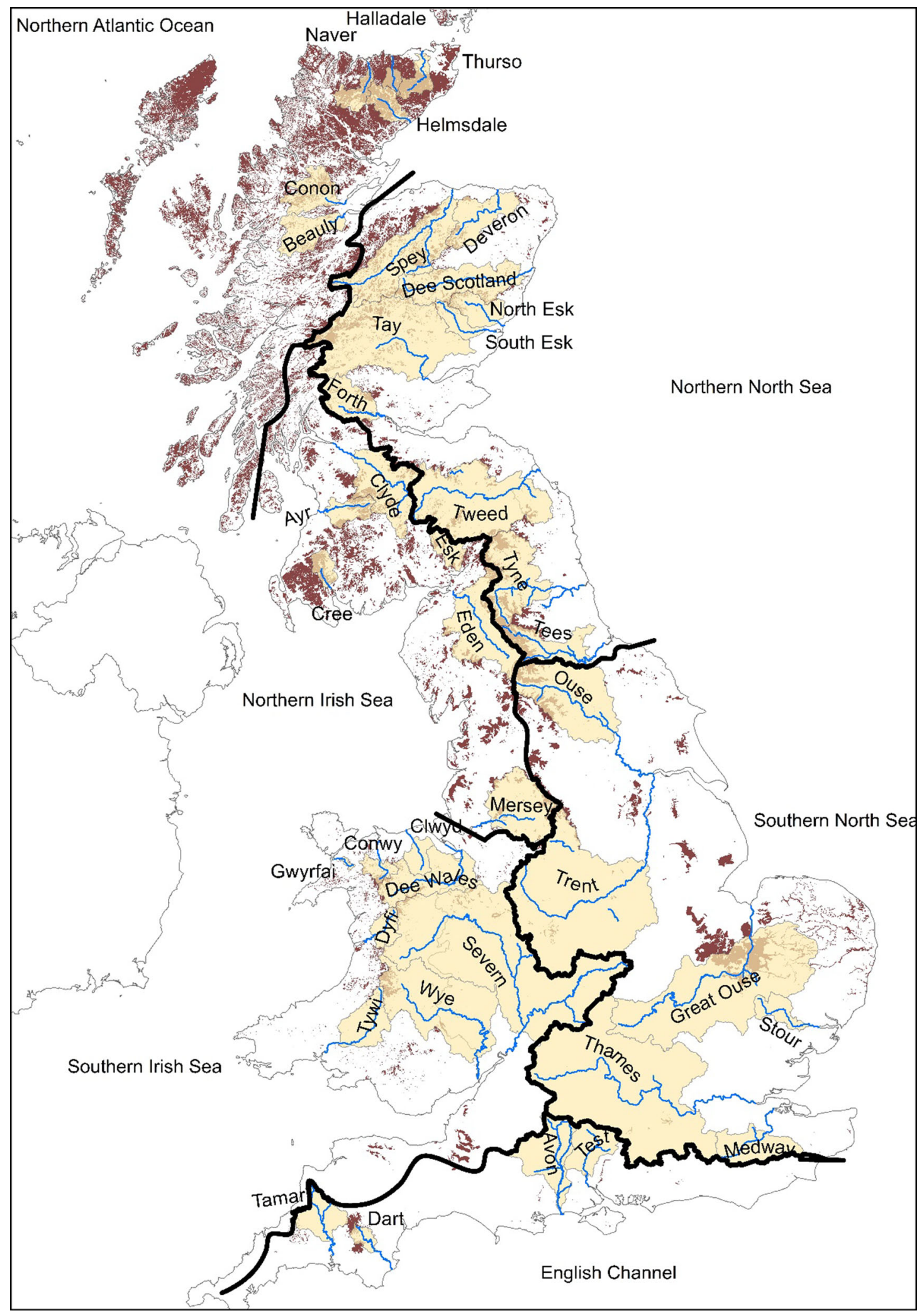


DOCflux $=k \frac{\sum_{i=1}^{n}\left[C_{i} Q_{i}\right]}{\sum_{i=1}^{n} Q_{i}} Q_{T}$

Other datasets used in the calculation

Fe additional datasets were used to support the spatial analysis of DOC fluxes from GB rivers. The CEH Wallingford Digital Terrain Model (Morris and Flavin 1990) was used to derive catchment boundaries and the mean altitude of the catchments. This dataset comprises a $50 \mathrm{~m}$ grid of elevation values with a vertical resolution of $0.1 \mathrm{~m}$. Ordnance Survey spot heights and hydrologically accurate digitised river channels were used during the development of this dataset.

The Met Office Standardised Annual Average Rainfall data covering the period 1961-1990 (SAAR 1961-90) were used to characterise spatial variations in catchment rainfall. This dataset consists of a $1 \mathrm{~km}$ grid of interpolated rainfall values based on measured rainfall and terrain characteristics including: relative geographical position, the ratio of land to sea within $3.5 \mathrm{~km}$, and elevation (Spackman 1993). This dataset provides consistent long-term average rainfall values across GB and was therefore considered a better basis for spatial analysis than local-scale or shorter-term monitoring.

The mean Base Flow Index (BFI) for each catchment was calculated from a $1 \mathrm{~km}$ grid of BFI across the UK. Theoretical BFI values range from $0-1$ and provide an indication of the proportion of base flow contributing towards overall river flow, with higher values indicating a greater proportion of base flow (Gustard et al. 1992).
Land cover data were derived from the $2015 \mathrm{CEH}$ Land Cover Map (LCM 2015) (Rowland et al. 2017) for all catchments, and compared to the GB land cover pattern. The land use data were derived two years prior to the water sampling taking place and it is assumed that only minor changes in land cover will have occurred in this period. The 21 broad habitat types within the LCM were grouped into larger, more internationally meaningful groupings for analysis to reduce the potential number of explanatory variables compared to the number of sampled rivers (Table 1). The selected catchments were a strong match to overall GB land cover (Fig. 2), with the major land cover classes being improved and neutral grassland (sampling catchments 30\%, GB 29\%) combined arable land (24\% for both) and woodland (13\% and

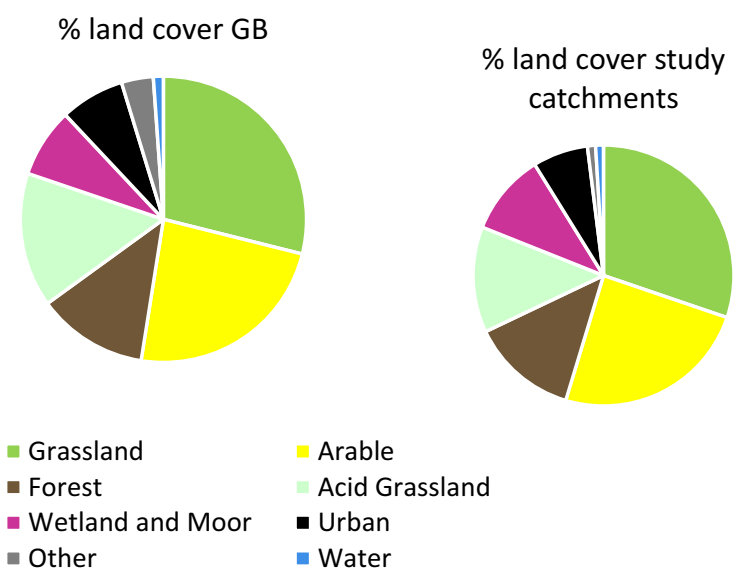

Fig. 2 Percent land cover in Great Britain (GB), as assessed by the Land Cover Map (LCM) 2015 and the percentage of land cover within all study catchments. Land cover types grouped as shown in Table 1

Table 1 Habitat groupings used for analysis of the effects of land cover on DOC concentrations and fluxes

\begin{tabular}{ll}
\hline Grouped habitat type & Original Centre for Ecology \& Hydrology Land Cover Map (LCM) 2015 broad habitat types included \\
\hline Arable & Arable and Horticulture \\
Forest & Conifer Woodland; Broadleaf Woodland \\
Wetland and Moor & Bog; Fen, Marsh and Swamp; Heather \\
Urban & Urban; Sub-urban \\
Acid Grassland & Acid Grassland; Heather Grassland \\
Grassland & Improved Grassland; Neutral Grassland; Calcareous Grassland \\
Water & Freshwater \\
Other & Inland Rock; Littoral Rock; Saltmarsh; Supralittoral Sediment; \\
& Supralittoral Rock; Saltwater; Littoral Sediment \\
\hline
\end{tabular}


$12 \%$ respectively). The study catchments had marginally lower cover of acid grassland compared to the GB total (13\% versus $15 \%)$ and higher wetland and moor (10\% versus $8 \%$; note that this category includes seminatural peatlands as well as wetland vegetation overlaying mineral and organo-mineral soils, see Table 1). 'Other' categories in this table include littoral and saltmarsh vegetation, which are underrepresented in the study catchments due to the requirement to sample above the tidal limit (indeed, small areas of these categories in the sampling catchments may indicate classification errors in the LCM dataset). Urban areas are also slightly underrepresented $(6.8 \%$ versus $7.2 \%)$ because many larger cities (including London) are located along the tidal sections of major rivers.

Peat soil presence, as defined by an organic soil greater than $40 \mathrm{~cm}$ depth in England and Wales and $50 \mathrm{~cm}$ depth in Scotland, was derived from existing soil maps, habitat mapping and soil surveying and combined into the first UK wide peat soil map (Evans et al. 2017a).

\section{Statistical analysis}

Backwards stepwise multiple linear regression analysis was used to determine the combination of environmental variables that best explained spatial variation in annual DOC concentrations, annual DOC yield and mean annual SUVA 254 . All possible combinations of terms were assessed using automated forwards stepwise regression and the effects of the order in which the explanatory variables were added within the regression analysis were tested to ensure that a priori assumptions about the likely drivers of the relationships did not unduly influence the outcome of the analyses. From these initial combinations highly correlated explanatory variables were assessed and only one was used in the final regression model. For example, wetland cover and peat soil cover positively correlated very strongly with each other, while arable land showed a strong negative correlation with rainfall. The initial automated regression analysis suggested that peat soil and rainfall were the variables that best explained DOC concentration and yield in each case so wetland cover and arable land cover were removed from the stepwise regression analysis. Where regressions gave a negative intercept this was set to zero, to avoid physically impossible negative estimates of concentrations and fluxes in some locations.

The resulting statistical model was applied to the entire GB landmass to estimate the annual GB DOC yield at a $1 \mathrm{~km}^{2}$ scale and the uncertainty associated with this value arising from the predictions intervals around the model coefficients for each parameter within the regression analysis was assessed using the "predict" function within the Stats package in R. The potential impact of forest and peat cover on DOC yields was estimated across a range of annual rainfall totals using the regression model described above. The current impact of forest cover on peat, and the potential for reducing DOC fluxes from afforested peatland soils, were assessed by comparing modelled DOC fluxes with and without forest cover on peat using ArcGIS v10.6. The DOC yield from peat soils with current land cover was calculated using the UK peat map developed by Evans et al. (2017a) to clip the GB modelled yield map in order to sum yields from cells containing peat. The potential reduction in yields that could be realised through removing forest from peat soils was estimated by recalculating emissions from the peat soil area with forest cover set to zero. This can be considered primarily an anthropogenic effect as the majority of forest cover on peat in GB is conifer plantation forestry. This assessment was carried out due to the current focus on peatland restoration by Governments and charities across GB. All analyses unless otherwise stated were carried out using R v 3.5.1 (R Core Team 2018).

\section{Results}

\section{DOC concentrations}

Mean annual flow weighted DOC concentrations ranged from 1.9 to $13.2 \mathrm{mg} \mathrm{C} \mathrm{L}^{1}$, with the highest concentrations observed in rivers draining large upland catchments in Northern England and Scotland (Fig. 3). Over all sampled sites, the mean DOC flow weighted concentration was $7.8 \mathrm{mg} \mathrm{L}^{-1}$, with a standard deviation of $3.0 \mathrm{mg} \mathrm{L}^{-1}$.

Equation 3 shows the best (lowest AIC) statistical relationship between catchment characteristics and DOC concentrations. This explained $68 \%$ of the variability in the flow weighted mean annual DOC concentration and suggests that DOC concentrations 


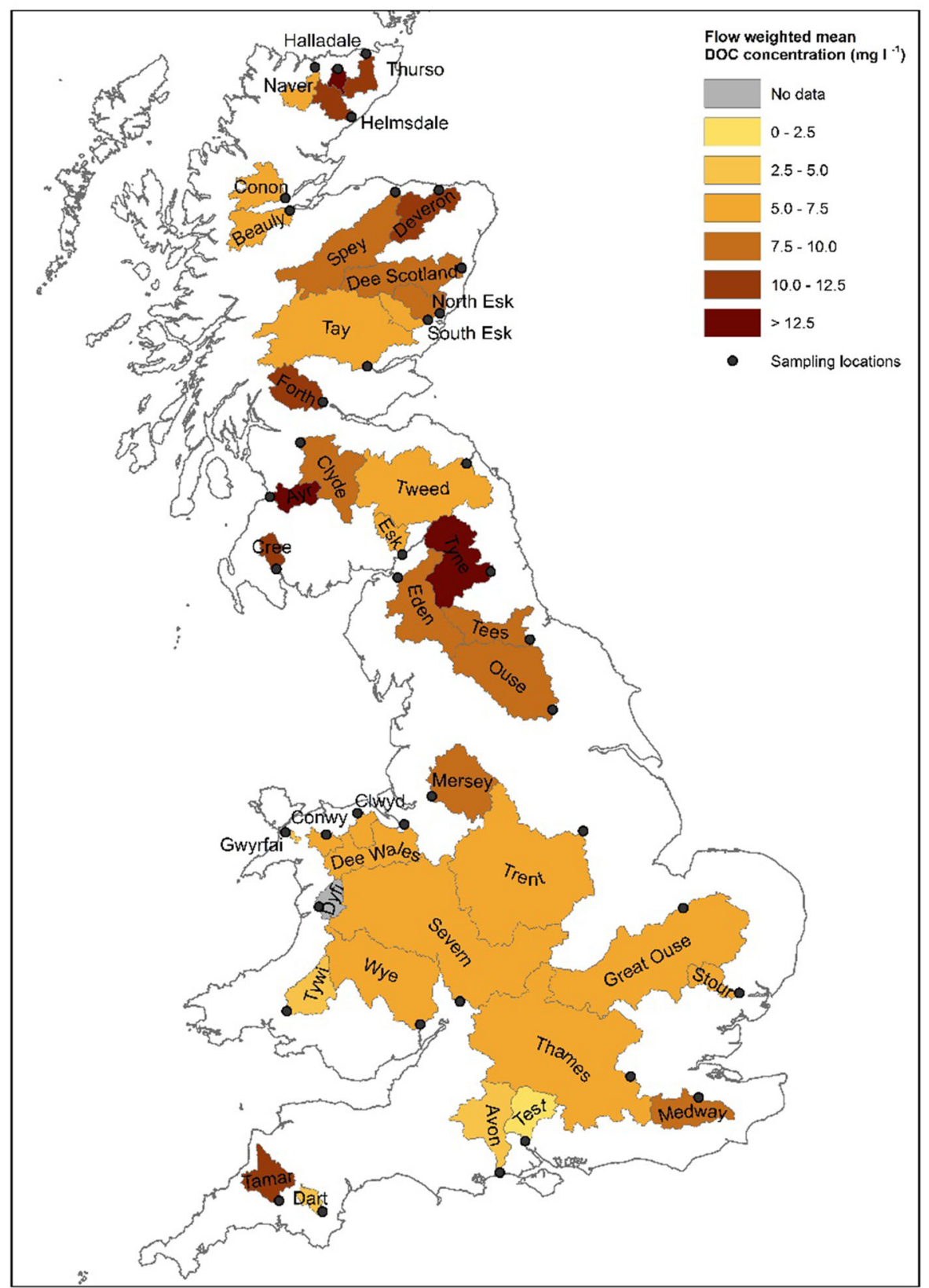

Fig. 3 Flow weighted mean dissolved organic carbon (DOC) concentrations determined during 2017. Outlines show the surface water catchments for each sampling location

tend to be larger in rivers draining catchments with high peat and grassland cover, a rapid hydrological response to rainfall, and high average elevation. The negative coefficient for rainfall implies that overall it exerts a diluting effect on DOC concentrations (Eq. 3).

$$
\begin{aligned}
{[D O C]=} & -0.004 * \text { SAAR }-10.27 * \text { BFI }+0.01 \\
& * \text { MeanAltitude }+0.09 * \text { Peatsoils } \% \\
& +0.06 * \text { Grass } \%+12.03
\end{aligned}
$$

$\mathrm{N}=39, \mathrm{R}^{2}=0.67$. SAAR $=$ Standardised average rainfall 1961-1990, BFI = Base Flow Index, Mean 
Altitude $=$ catchment mean altitude, all other variables refer to the percentage cover within the catchment.

\section{C export and yields}

The total 2017 DOC export from the rivers sampled during this study was $290 \mathrm{Gg}$, with the largest DOC yields observed in the Ayr and Cree catchments in South-west Scotland (20.2 and $14.4 \mathrm{~g} \mathrm{C} \mathrm{m}^{-2}$ year $^{-1}$ respectively), followed by the Halladale and Conon in Northern Scotland and the Conwy in North Wales (Fig. 4). The lowest DOC yields were from the Great Ouse in Eastern England $\left(0.31 \mathrm{~g} \mathrm{C} \mathrm{m}^{-2}\right.$ year $\left.^{-1}\right)$, an area with low rainfall and heavily modified land usage. Equation 4 shows the best (lowest AIC) statistical relationship between catchment variables and DOC yield. This relationship explained $90 \%$ of the variability in DOC yield and suggests that this variability can be explained by rainfall, the percentage cover of peat soils and the percentage cover of forest within a catchment (Eq. 4).

$$
\begin{aligned}
\text { DOCyield }= & 0.002 * \text { SAAR }+0.096 * \text { Peatsoils } \% \\
& +0.113 * \text { Forest } \%
\end{aligned}
$$

$\mathrm{N}=39, \mathrm{R}^{2}=0.90$. DOC yield $\left(\mathrm{g} \mathrm{C} \mathrm{m}^{-2}\right.$ year $\left.^{-1}\right)$, SAAR $=$ Standardised average rainfall 1961-1990 $\left(\mathrm{mm}\right.$ year $\left.{ }^{-1}\right)$, all other variables refer to the percentage cover within the catchment.

Measured DOC yields, were separated into the Northern Atlantic (rivers draining into the sea on the north coast of Scotland), the northern and southern North Sea, the English Channel and the northern and southern Irish Sea, with the boundary defined by the Mersey estuary (See Fig. 1). Mean DOC yields were highest for rivers draining into the northern Irish Sea, at $11.2 \mathrm{~g} \mathrm{C} \mathrm{m}^{-2}$ year $^{-1}$, followed by the North Atlantic at $10.1 \mathrm{~g} \mathrm{C} \mathrm{m}^{-2}$ year $^{-1}$. Yields for rivers flowing into the northern North Sea and southern Irish Sea were similar, with means of 5.5 and $5.4 \mathrm{~g} \mathrm{C}$ $\mathrm{m}^{-2}$ year $^{-1}$ respectively, while yields for rivers draining to the English Channel and southern North Sea were lowest (3.6 and $1.3 \mathrm{~g} \mathrm{C} \mathrm{m}^{-2}$ year $^{-1}$ ).

Equation 4 was used to estimate the DOC yields that would be delivered to the tidal limit from a hypothetical set of catchments comprising $100 \%$ peat soil cover, $100 \%$ forest cover and $100 \%$ forest cover on peat soil, for a range of rainfall values (Table 2). The data suggest a 'baseline' DOC yield from (naturally unforested) peatlands of around 10 to $16 \mathrm{~g}$ $\mathrm{C} \mathrm{m}{ }^{-2}$ year $^{-1}$. The presence of forest-which for most upland areas of Britain is dominated by planted non-native conifers rather than native broadleaf woodland-generally increases DOC yields. This is amplified where conifers are planted on peat (a process which generally also involves peat drainage), giving DOC yields that are approximately double those from unforested peatland at equivalent rainfall levels.

DOC composition

Mean annual $\mathrm{SUVA}_{254}$ values were highest in the rivers draining Northern Scotland, Southwest Scotland and Northern England (Fig. 5). Annual rainfall and peat cover were again among the strongest predictors of $\mathrm{SUVA}_{254}$, implying that the conditions that give rise to high DOC yields also generate more aromatic DOC; this is also apparent in a direct comparison of mean SUVA $_{254}$ and mean DOC yields across all sites (Fig. 6). Mean catchment altitude, as well as higher coverage of both acid and improved grassland, also positively influenced mean $\mathrm{SUVA}_{254}$ (Eq. 5).

$$
\begin{aligned}
\text { SUVA }= & -0.0007 * \text { SAAR }+0.004 * \text { MeanAltitude } \\
& +0.03 * \text { Peat } \%+0.024 * \text { AcidGrassland } \% \\
& +0.014 * \text { Grassland } \%+2.23
\end{aligned}
$$

$\mathrm{N}=40, \mathrm{R}^{2}=0.79$. Variables as described in Eq. 3 .

GB-scale DOC export

Gridded DOC yields, based on Eq. 4, are shown in Fig. 7. Note that this extrapolation effectively predicts the source of observed DOC flux at the sampling points close to the tidal limit, and thus cannot strictly be considered a map of the DOC produced by each grid cell (i.e. if in-river DOC removal is occurring, 'effective' yields may be smaller than 'true' yields). Nevertheless, this analysis reveals some clear spatial patterns in the sources of DOC export from the GB land area, and also has the advantage that fluxes from areas outside the larger sampled drainage basins can be inferred. The highest DOC yields are associated with the afforested peatlands of Northern and Southwest Scotland, and Northern England. The general 


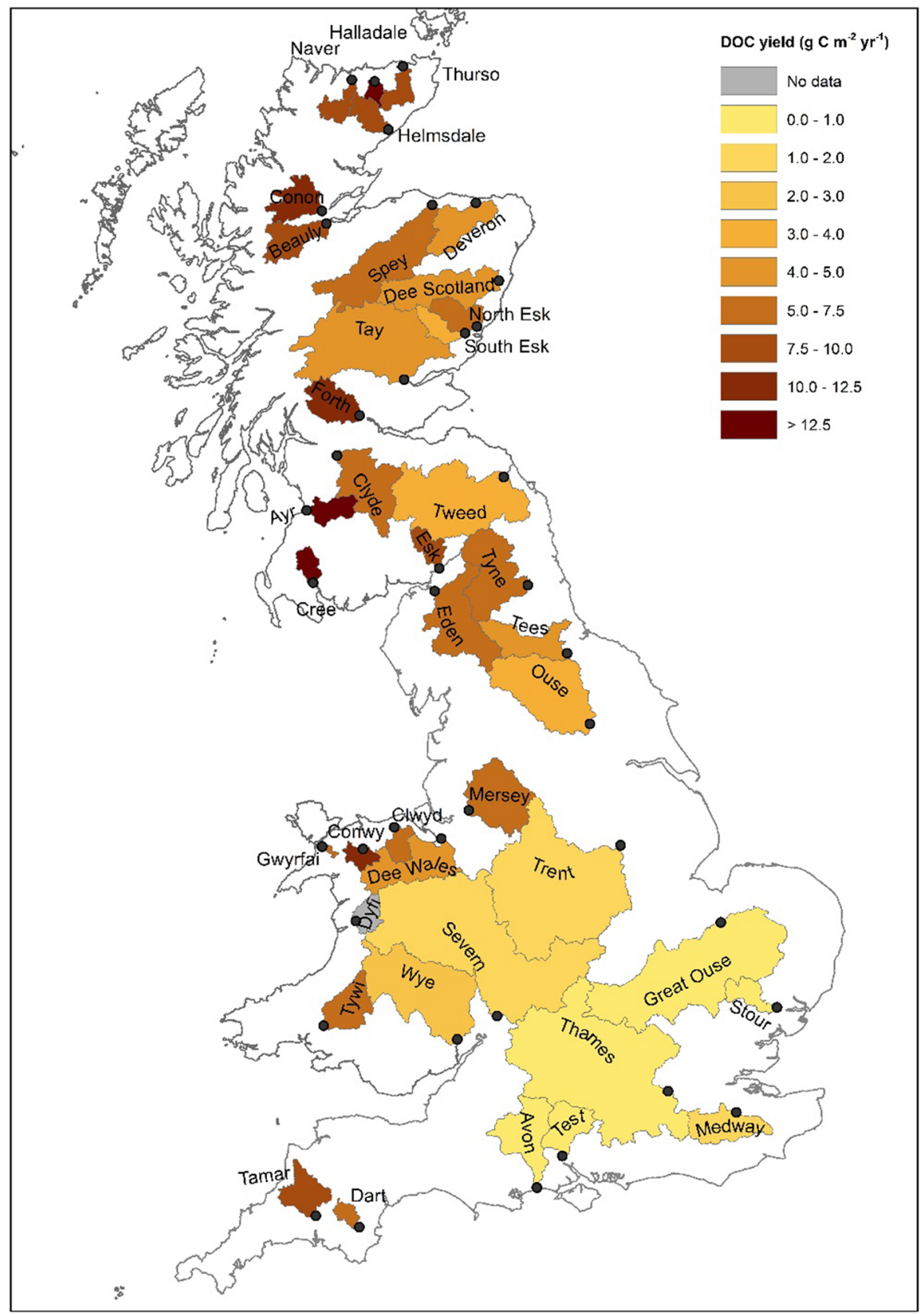

Fig. 4 Dissolved organic carbon (DOC) yields $\left(\mathrm{g} \mathrm{C} \mathrm{m}^{-2}\right.$ year $\left.^{-1}\right)$ determined during 2017. Outlines show the surface water catchments for each sampling location

increase in DOC yields from Southeast to Northwest reflects both the gradient in rainfall and the (linked) increase in peat cover along this gradient. Based on this extrapolation, total DOC export from the GB land mass in 2017 was estimated to be $1.15 \mathrm{Tg} \mathrm{C}_{\text {year }}{ }^{-1}$, with a modelled uncertainty range from 0.96 to 1.35
Tg C year ${ }^{-1}$. This gives a countrywide mean DOC yield of $5.04 \mathrm{~g} \mathrm{C} \mathrm{m}^{-2}$ year $^{-1}$.

In terms of the destination of modelled DOC, export to the North Atlantic was highest at $0.21 \mathrm{Tg} \mathrm{C}$, and lowest to the English Channel (0.07 Tg C during 2017). The Irish Sea received a total of $0.35 \mathrm{Tg}$ of 
Table 2 Modelled DOC yields for a hypothetical set of catchments with $100 \%$ peat cover, $100 \%$ forest cover and $100 \%$ forest on peat over a range of annual rainfall values $(\mathrm{mm})$

\begin{tabular}{llll}
\hline Annual rainfall $(\mathrm{mm})$ & \multicolumn{3}{l}{ Modelled DOC yield $\left(\mathrm{g} \mathrm{C} \mathrm{m}^{-2} \mathrm{year}^{-1}\right)$} \\
\cline { 2 - 4 } & $100 \%$ peat & $100 \%$ forest & $100 \%$ forest on peat \\
\hline 500 & 10.6 & 12.3 & 21.9 \\
1000 & 11.6 & 13.3 & 22.9 \\
1500 & 12.6 & 14.3 & 23.9 \\
2000 & 13.6 & 15.3 & 24.9 \\
2500 & 14.6 & 16.3 & 25.9 \\
3000 & 15.6 & 17.3 & 26.9 \\
\hline
\end{tabular}

terrestrial DOC export $(0.16 \mathrm{Tg}$ to the southern area, $0.19 \mathrm{Tg}$ to the northern area), and the North Sea received a similar total DOC export of $0.38 \mathrm{Tg}$ split evenly between the northern and southern areas.

GB scale estimates suggest that forest planting (primarily conifer) may have raised the GB DOC export flux by $0.17 \mathrm{Tg}$ DOC year ${ }^{-1}$; with forests on peat accounting for $0.045 \mathrm{Tg}$ of this.

Gridded predictions of $\mathrm{SUVA}_{254}$ (Fig. 8) also show geographic variation, largely corresponding to variations in peat cover, but with a less pronounced influence of rainfall, such that high $\mathrm{SUVA}_{254}$ values are also predicted for drier areas such as Eastern Scotland and the lowland (fen) peats of Eastern England.

\section{Discussion}

GB scale DOC export and uncertainties

This study estimates whole GB DOC export and yield based on a dedicated and standardised sampling and analytical programme. Previous syntheses of GB data (e.g. Hope et al. 1997; Worrall et al. 2012, 2018) have relied on data collected by regional agencies usually for a different original purpose, and do not always cover all regions of GB; for example Worrall et al. (2012) has very little data from the north of Scotland where high DOC export was predicted. This study also used directly measured DOC concentrations, rather than absorbance-based proxies such as those used by Worrall et al. (2012) and the consistent timing of sample collection across all sites minimised the influence of short-term meteorological variability on spatial patterns, permitting robust empirical relationships to be derived between DOC concentration, yield and quality, and a range of spatial predictor variables.
Application of these empirical relationships to gridded spatial data allowed us to make a comprehensive estimate of the total land-ocean DOC export from the British land area that incorporated unsampled catchments, and areas discharging directly to the coast, estuaries and tidal rivers.

Our estimated annual export of DOC from the British land mass in 2017 of $1.15 \mathrm{Tg} \mathrm{C}$ year $^{-1}$ lies at the upper end of previous estimates, which range from $0.69 \mathrm{Tg} \mathrm{C}$ year $^{-1}$ (Hope et al. 1997) and 0.91 Tg year $^{-1}$ (Worrall et al. 2012) to a one-year maximum flux of $1.3 \mathrm{Tg} \mathrm{C}$ year $^{-1}$ reported by Worrall et al. (2018) for 2005 (their long-term mean estimated flux was $0.86 \mathrm{Tg} \mathrm{C}$ year $^{-1}$ ). Based on this comparison, our data suggest that the riverine export of DOC from Great Britain may be higher than previously estimated. As previous studies (Worrall et al. 2012, 2018) have used absorbance data as a proxy for DOC concentration from a number of their sites they would not have detected non-coloured DOM (e.g. Pereira et al. 2014) so their values may have under-estimated noncoloured DOM exported from rivers, and hence under-estimated total DOC export.

While the best-fit DOC model explained $90 \%$ of the variation in the measured data, a number of uncertainties remain in our upscaled flux estimate. Our calculated range of $0.96-1.35 \mathrm{Tg} \mathrm{C}$ lost from the GB landscape per year includes uncertainty in the linear regression parameters-rainfall, peat and forest cover-but does not account for uncertainty in the categorisation of land cover at a $1 \mathrm{~km}^{2}$ scale, the spatial mapping of peat soils across GB, the upscaling of the rainfall totals, or upscaling of monthly samples to annual fluxes. It is also possible that some additional export of DOC via groundwater flow directly to the sea is not accounted for, although given low groundwater DOC concentrations (typically between $1-3 \mathrm{mg} \mathrm{l}^{-1}$ ) this may be a minor contribution at the GB scale, 


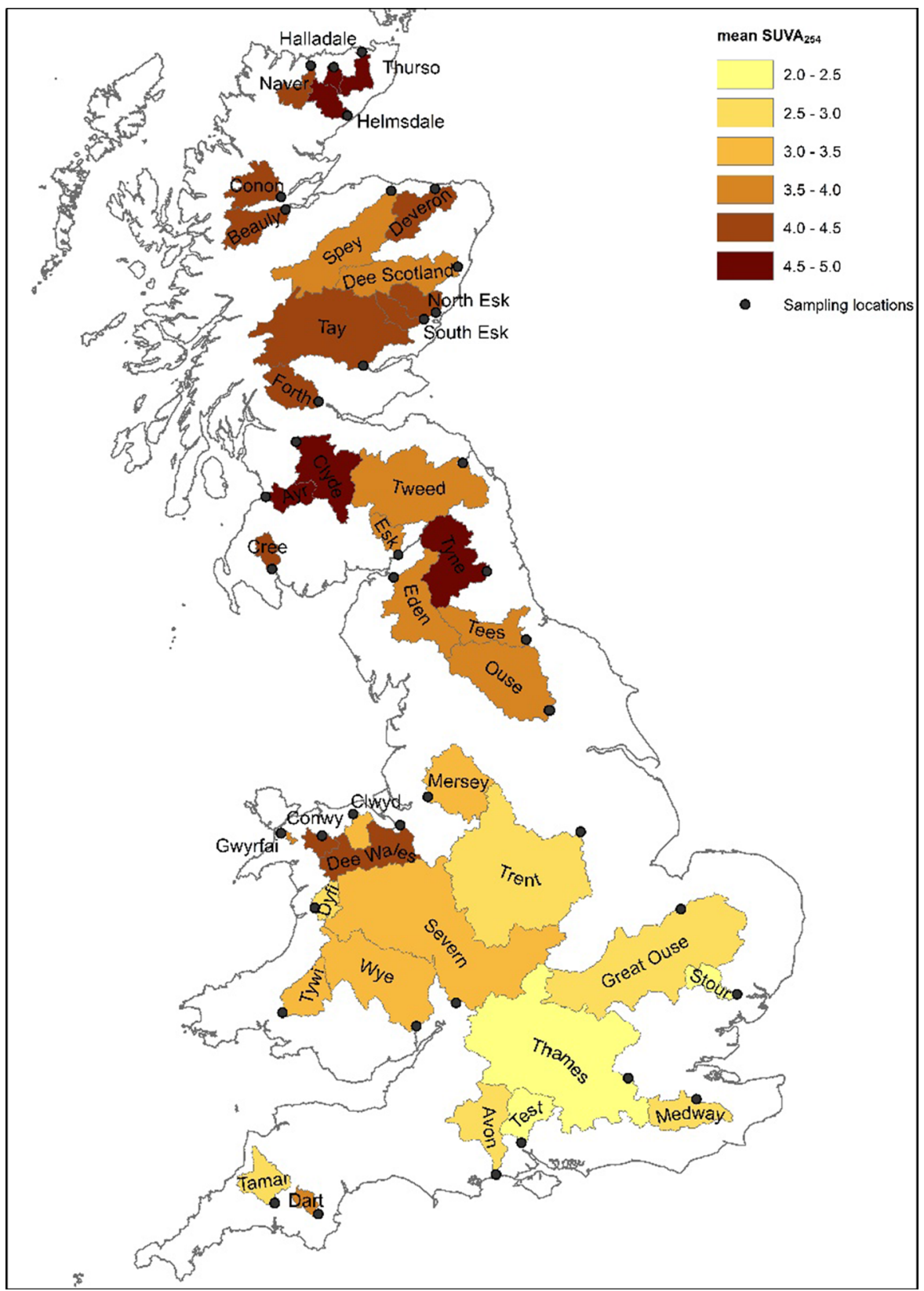

Fig. 5 Mean annual SUVA $_{254}$ (specific UV absorbance at $254 \mathrm{~nm}$ ) determined during 2017. Outlines show the surface water catchments for each sampling location

depending on the volume of submarine groundwater discharge, which has not been quantified (Stuart and Lapworth 2016). With regard to long-term DOC fluxes, our estimate is based on a single year, which may not be typical of the longer-term conditions, especially given that both upland-derived and wastewater inputs of DOC have been changing during recent decades (Monteith et al. 2007; Worrall et al. 2019). The potential inter-annual variability in the DOC flux is not covered in this work, with potential sources of variation arising from the water flux from the rivers and from changes in DOC concentration. Records from the National River Flow Archive (www. nrfa.ceh.ac.uk) show that river flows in 2017 were 


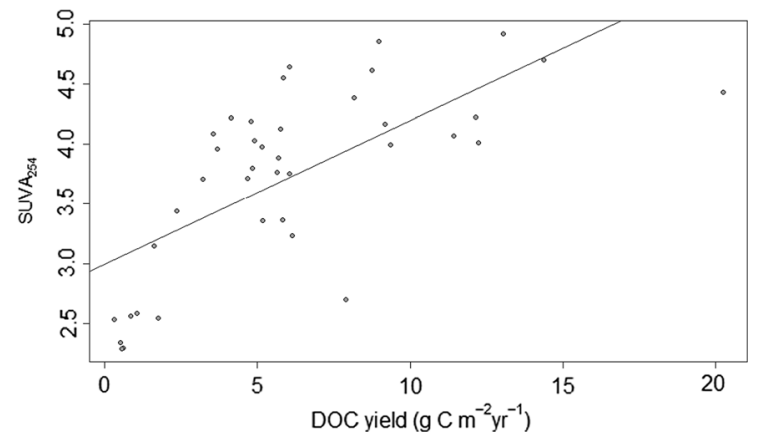

Fig. 6 Relationship between annual dissolved organic carbon (DOC) yield and SUVA 254 (specific UV absorbance at $254 \mathrm{~nm}$ ). $\mathrm{R}^{2}=0.46, \mathrm{P}=0.000001$

similar to the previous five years, suggesting that DOC exports calculated for 2017 are indicative of the shortterm conditions across GB.

A further source of uncertainty in the regression model is that all peatland soils are treated as a homogenous entity, despite there being considerable variation in peat soil type (e.g. fen versus bog, upland versus lowland) and condition (drained, burned, near natural etc.), some of which have been suggested to influence DOC concentrations in waters draining peat soils (e.g. Evans et al. 2016; Yallop et al. 2010). At present, however, no sufficiently comprehensive national scale data are available that would permit this information to be used in the flux model. Future developments in remote sensing of peatland condition (e.g. Williamson et al. 2018) may allow for the future refinement of the present model. Nevertheless, the strong empirical relationships between our observed DOC fluxes and available spatial data permit us to draw some initial conclusions about the influence of land-use.

The influence of land-use

Our analysis of spatial controls on DOC concentrations, yields and quality all suggest a dominant influence of intrinsic catchment factors such as peat cover, rainfall and altitude. This is broadly in agreement with the main drivers found by Hope et al. (1997), who showed that rainfall and coverage of organic soils were the most important drivers affecting riverine DOC export, and with global-scale analyses such as that of Aitkenhead and McDowell (2000). We found little evidence that human activities in lowland areas, such as urbanisation or arable and livestock farming, were having a strong effect on overall DOC export. This is somewhat in contrast to the findings of Worrall et al. (2012) and Worrall et al. (2018), who observed a strong influence of urban sources on DOC in lowland rivers, and with global analyses such as that of Butman et al. (2015) who identified a signal of agriculture and urbanisation on radiocarbon levels in DOC. However, the analyses of Worrall et al. (2012) also showed that the influence of urban areas has declined sharply since the implementation of the European Urban Wastewater Treatment Directive in the early 1990s, so it is possible that this signal may no longer be so strongly evident in our 2017 data. Conversely, there has been a strong trend towards increasing DOC concentrations in GB headwater catchments since at least the 1980 s, in some cases by a factor of two, which has been attributed to an increase in the solubility of soil organic matter in response to large reductions in acid deposition (Evans et al. 2012; Monteith et al. 2007). This could have increased the dominance of the 'upland' signal in our dataset, although it contrasts with the findings of Worrall et al. (2018) that the GB DOC flux has declined since peaking in 2005. Their conclusion was that the 'upland' signal may have been masked by a combination of in-river processing and declining urban wastewater inputs. Elsewhere in Northern Europe, where similar increases in headwater DOM have occurred, there does appear to be evidence that increases in DOC production from organic-rich headwater catchments have propagated through to increased DOC export from rivers to estuaries (Kritzberg and Ekstrom 2012; Raike et al. 2016). While our one-year dataset does not provide new information on the long-term trajectory of DOC flux changes, the apparent dominance of upland DOC sources in our large-river dataset appears consistent with the evidence from other studies that changes in headwater DOC production are in most cases likely to translate into changes in DOC export at the large river scale.

The only land-use related factor found to affect DOC flux in our analysis was the presence of forests, which to a large extent in the British uplands comprise non-native conifer plantations. The presence of forestry appears to consistently enhance DOC export, and this effect is amplified where forests are planted on peat soils, which will have been drained prior to 


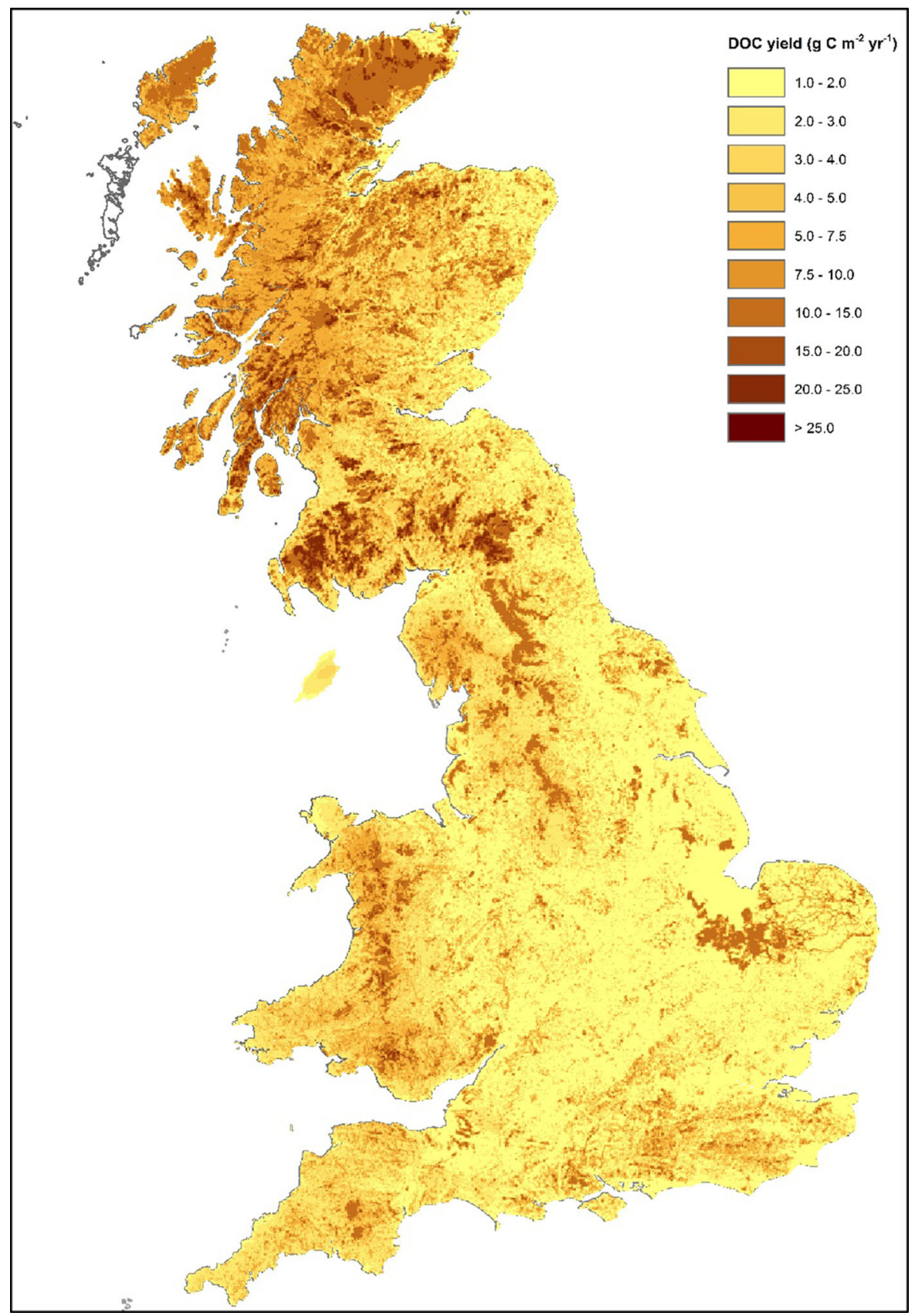

Fig. 7 modelled annual dissolved organic carbon (DOC) yields $\left(\mathrm{g} \mathrm{C} \mathrm{m}^{-2}\right.$ year $^{-1}$ ) at a $1 \mathrm{~km}$ grid scale across GB. Note that this extrapolation effectively predicts the source of observed DOC

planting to lower the water table sufficiently to allow conifers to grow. This observation is consistent with previous work suggesting that drained and afforested peatlands tend to have elevated DOC export (Evans et al. 2016; Menberu et al. 2017; Skerlep et al. 2019) flux at the sampling points close to the tidal limit, and thus cannot strictly be considered a map of the DOC produced by each grid cell

and with a recent targeted study of forested versus unforested blanket bogs in Northern Scotland (Pickard et al. in prep.). The mapped spatial distribution of the DOC yields across GB reflects this land-use influence, with the highest yields observed from the afforested 


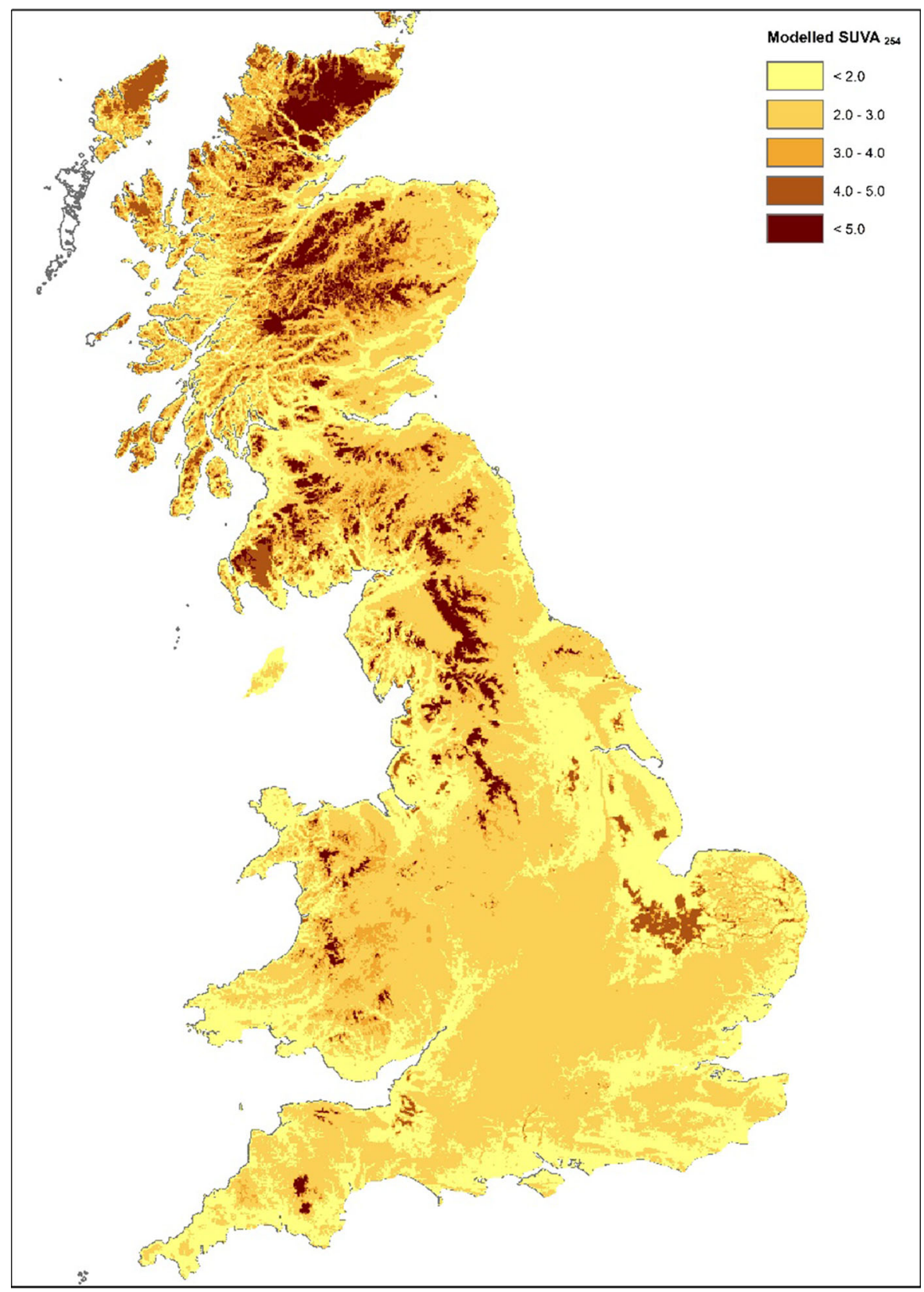

Fig. 8 Modelled SUVA 254 (specific UV absorbance at $254 \mathrm{~nm}$ ) for Great Britain at a $1 \mathrm{~km}$ grid scale. Note, this is an extrapolation predicting the source of DOC with a given $\mathrm{SUVA}_{254}$ value at the tidal limit, and is not strictly a map of SUVA 254 at each grid cell

peatlands of Southwest Scotland, Northern Scotland and Northern England. In total, we estimate the influence of conifer afforestation on DOC export at the GB scale to be up to $0.17 \mathrm{Tg} \mathrm{C}$ year $^{-1}$. Across GB there is a move towards peatland restoration, including the conversion of forestry plantation back to blanket bog, particularly in the Flow Country of northern
Scotland, where large areas of peatland have been impacted by conifer plantation. We estimate that across GB the presence of conifer on peat generates an additional $0.045 \mathrm{Tg} \mathrm{C}$ year $^{-1}$ in DOC export, a value which, although relatively small in overall terms, represents $4 \%$ of the DOC export from a land use covering $1.5 \%$ of the GB land mass. More broadly, 
there is currently a strong policy drive to increase tree cover throughout all countries of the UK, as in many other countries, with the aim of sequestering $\mathrm{CO}_{2}$ from the atmosphere in order to meet national targets for 'net zero' greenhouse gas emissions (Bastin et al. 2019; CCC 2020). Given that the UK has been heavily deforested since pre-history, the re-establishment of tree cover can hardly be considered an anthropogenic perturbation. On the other hand, forest expansion during the last century has largely involved the planting of exotic conifer species on organic-rich upland soils, rather than on the agriculturally productive lowland mineral soils that are more favourable to native broadleaf species. Our analysis suggests that the continuation of this policy could have implications for the magnitude of $\mathrm{CO}_{2}$ uptake that can be achieved; the $0.17 \mathrm{Tg} \mathrm{C}$ year $^{-1}$ of forest-related DOC export from GB rivers equates to $15 \%$ of the estimated net $C$ uptake by growing trees in the UK after accounting for reemission via Harvested Wood Products (Brown et al. 2019).

The fate of DOC exported from GB rivers, and therefore their impact on greenhouse gas budgets, remains uncertain. Some DOC is likely to be mineralised to $\mathrm{CO}_{2}$ and lost to the atmosphere in estuaries, coastal shelf seas or the deep ocean, but a proportion may be flocculated and buried in sediments, while a proportion of the mineralised DOC may enter the stable ocean DIC pool. Recent studies suggest that flocculation may be a relatively minor sink (Anderson et al. 2019) whereas biological and photochemical degradation of DOC in marine systems may take years to decades (Catalan et al. 2016), such that this removal is difficult to detect even in large-scale studies (e.g. Painter et al. 2018). As a 'worst case' scenario, assuming complete mineralisation of DOC exported from GB river systems and the subsequent degassing of $\mathrm{CO}_{2}$ to the atmosphere, this would generate a maximum emission of $4.2 \mathrm{Tg} \mathrm{CO}_{2}$ year $^{-1}$, with the 'anthropogenic' (i.e. forestry-related) component being $0.62 \mathrm{Tg} \mathrm{CO}_{2}$ year $^{-1}$. Based on this assumption (and omitting any mineralisation of DOC in the drainage network above the sampling sites) $\mathrm{CO}_{2}$ emissions associated with riverine DOC export would be equivalent to $1 \%$ of the UK's total reported anthropogenic $\mathrm{CO}_{2}$ emissions for 2017 (Brown et al. 2019). While some caution is required when directly comparing these values, our data clearly suggest that the land-ocean flux of $\mathrm{C}$ through British rivers is a non-trivial component of the overall natural and anthropogenic $\mathrm{C}$ cycle. This finding supports other studies that have suggested significant anthropogenic enhancement of land-ocean C fluxes (e.g. Moore et al. 2011; Raymond et al. 2008; Regnier et al. 2013).

Spatial variations in DOM composition

A comparison of $\mathrm{SUVA}_{254}$ values against the DOC yields from the monitored river catchments shows that, generally, the rivers with the highest DOC yields also tended to have the highest $\mathrm{SUVA}_{254}$. High $\mathrm{SUVA}_{254}$ is indicative of more aromatic organic compounds (Weishaar et al. 2003), which tend to be resistant to biodegradation, but more susceptible to photodegradation (e.g. Berggren et al. 2018; Cory et al. 2015; Koehler et al. 2016). In the GB rivers used in this study, $\mathrm{SUVA}_{254}$ was primarily linked to peatland cover in the catchment, a finding also seen in rivers in North America (Hanley et al. 2013; Wollheim et al. 2015), the Arctic (O'Donnell et al. 2016) and Africa (Lambert et al. 2016, 2015). Despite its low biodegradability, several studies have shown that high-SUVA 254 DOM may be preferentially removed in both streams (Wollheim et al. 2015) and lakes (Kohler et al. 2013) due to its high photodegradability, and possibly also its greater susceptibility to flocculation and removal via sedimentation. It has been estimated that as much as $73 \%$ of high-SUVA 254 peat-derived DOM could be photodegraded in GB river systems within a 10 day period (Moody et al. 2013). Some previous studies of UK and Scandinavian catchments have suggested that as much as $70 \%$ of soil derived DOM can be removed prior to river water reaching the coast (Tranvik et al. 2009; Worrall et al. 2012). A global meta-analysis suggested a general reduction in $\mathrm{SUVA}_{254}$ is seen in waters on a downstream pathway from wetlands, to rivers, to estuaries, to oceans, suggesting that aromatic photodegradable DOC is progressively removed from the system (Massicotte et al. 2017). The positive effect of mean altitude on $\mathrm{SUVA}_{254}$ may be linked to the steepness of the catchment, with catchments with higher altitude being generally steeper in GB, and hence with faster water flows and shorter residence times meaning less opportunity for photodegradation of DOC. The positive influences of both acid grassland and improved grassland cover (which positively influences both DOC concentration and $\mathrm{SUVA}_{254}$ ) are harder to 
interpret. It is likely that within GB upland areas are dominated by soils with relatively high organic matter content and overlain by acid grassland; while it is possible that soil treatments such as liming may increase soil $\mathrm{pH}$ and hence humic DOC solubility (Evans et al. 2012), which would have the effect of increasing both DOC concentration and $\mathrm{SUVA}_{254}$. These factors may be more specific to the GB land mass, while the effect of peat soils on $\mathrm{SUVA}_{254}$ appears to be more universal.

Our data indicate that a significant proportion of high-SUVA 254 DOC remains at the river-estuary interface in many GB rivers. This persistence of photodegradable material through the freshwater system likely reflects the short transit time of water through many of the shorter British upland-dominated river systems, as well as the lack of large lakes or impoundments in the lower reaches of most of the sampled rivers. The limited depth of light penetration in high-DOM waters may also limit photodegradation rates (Berggren et al. 2018; Koehler et al. 2014). These factors will all tend to shift DOC degradation processes downstream to the coastal zone.

Rivers draining the lowland regions of Southern England had lower-SUVA 254 DOC, and are therefore more likely to be exporting proportionally more bioavailable DOC than photodegradable DOC to the estuarine zone. These rivers largely drain mineral soils used for agriculture, as well as urban areas, and therefore receive lower inputs of soil-derived DOC, but higher inputs of nutrients and potentially also wastewater and faecal derived DOC. The larger catchments, slower flows, and consequently longer residence times for water in lowland rivers are likely to favour photolysis of humic DOC. On the other hand, biological consumption of more labile catchmentderived DOM is likely to be offset by autochthonous DOC production under high nutrient conditions (Evans et al. 2017b; Graeber et al. 2015; Lambert et al. 2017). Together, these processes would have the effect of lowering the $\mathrm{SUVA}_{254}$ values of river samples, while maintaining a modest export of DOC to the coastal zone.

Previous work has clearly shown that terrigenous DOC is present in shelf seas (Painter et al. 2018; Yamashita et al. 2011), and there is some evidence that recent increases in riverine DOC concentrations across Northern Europe (e.g. Kritzberg and Ekstrom 2012; Monteith et al. 2007) may have affected terrigenous organic matter levels in the Baltic (Voss et al. 2011), although changes have not been detected (based on snapshot surveys rather than monitoring) in the North Sea (Painter et al. 2018). Painter et al. (2018) showed that the DOM reaching the coastal waters of the North Sea from the east coast of England and Scotland had lower-SUVA 254 , and is therefore likely more bioavailable, than the GB average. This material may be turned over more rapidly, or less easily distinguished from DOM produced autochthonuously within the marine system, than the high $\mathrm{SUVA}_{254} \mathrm{DOM}_{\text {exported }}$ from the northern and western GB. Indeed, the high SUVA $_{254}$ values seen by Painter et al. (2018) around the north of Scotland may be linked to the outflows of the rivers draining the peat soils of this area, particularly in late summer when their sampling took place.

GB-scale DOC fluxes in a global context

Global estimates of DOC export from rivers to the ocean are in the region of $0.17-0.78 \mathrm{Pg} \mathrm{C}_{\text {year }}{ }^{-1}$ (Dai et al. 2012), with more recent estimates appearing to converge towards the lower end of this range (Ciais et al. 2013; $\mathrm{Li}$ et al. 2017). The similarity in range and order of magnitude of the recent estimates is due in part to the constraint of global DOC flux models by river discharge, which is relatively well modelled (Dai et al. 2012). However Huang et al. (2012) have estimated that tropical rivers alone export $0.14 \mathrm{Pg} \mathrm{C}$ year $^{-1}$ as DOC, and Baum et al. (2007) calculated that Indonesia's rivers alone (which are omitted from most global analyses) could generate $0.02 \mathrm{Pg}$ DOC annually, which is approximately $10 \%$ of global riverine DOC export. These observations, together with the more general under-representation of smaller peatrich river catchments in global datasets discussed earlier, could indicate that the true global riverine DOC flux is somewhat higher.

Figure 9 shows estimates of DOC yields for the world's largest rivers by discharge (Raymond and Spencer 2015); from previous GB-scale flux assessments (Hope et al. 1997; Worrall and Burt 2007; Worrall et al. 2012) and from comparable nationalscale estimates for Norway (De Wit et al. 2015), Finland (Raike et al. 2016), Indonesia (Baum et al. 2007) and the conterminous United States (Stets and Striegl 2012). As has already been noted, our estimates of DOC yields for GB are of a similar magnitude to, but somewhat higher than, previous estimates, 


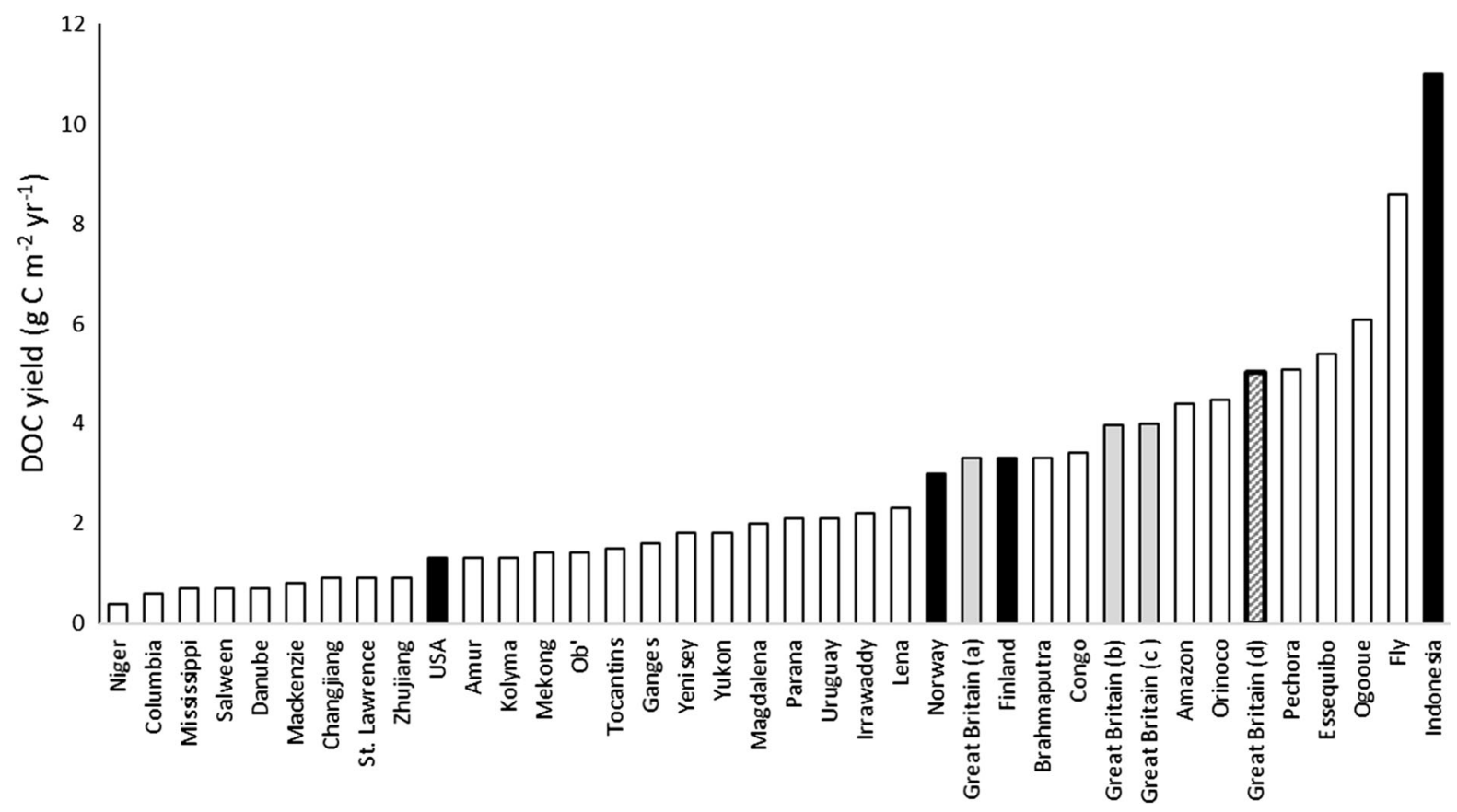

Fig. 9 Comparison of dissolved organic carbon (DOC) yield from major world rivers (white bars), available country scale estimates (black bars) and previous GB-scale studies (grey bars) and this study (bold outline and diagonal shading, denoted (d) on the $x$ axis). All river data from Raymond and Spencer (2015),

possibly due to our extrapolation from sampled larger rivers to unsampled smaller (and in some areas peatrich) areas, or due to observed long-term increase in GB headwater DOC concentrations (Monteith et al. 2007) since the earlier studies were undertaken. Compared to the large river dataset of Raymond and Spencer (2015), DOC yields for GB rivers are similar to or higher than those observed for many of the great rivers of the humid tropics, including the Amazon and Congo. They are consistently higher than those of most large temperate river systems, and of most of the major Siberian and North American rivers draining to the Arctic Ocean. Compared to other national-scale estimates, estimated DOC yields for GB are higher than those for the conterminous US and Norway, similar to those from Finland, and lower than those for Indonesia. Our results are broadly consistent with the analysis of Li et al. (2017) who observed highest DOC yields in areas of high soil carbon content and high runoff, including many smaller drainage basins in Northern Europe, Eastern Canada and Southeast Asia.

Comparing our results to the analysis of Aitkenhead and McDowell (2000) our predicted DOC yields from country data from De Wit et al. (2015, Norway), Stets and Striegl (2012, USA), Raike et al. (2016, Finland), Baum et al. (2007, Indonesia), and Hope et al. (1997), Worrall and Burt (2007) and Worrall et al. (2012) (GB, denoted (a), (b) and (c) respectively on the $\mathrm{x}$ axis)

peatlands are similar to those of their UK peatland catchments, but higher than their boreal peatland sites, which were all located in Finland, an area of lower average runoff. In general, our estimated DOC yields from forested catchments were higher than the global mean for forests, which may reflect the managed nature of the landscape within many GB conifer plantations, and predominance of forestry on organic soils. The main drivers of rainfall, organic soil coverage and forest cover shown by this dataset have also been found to be important on a global scale, suggesting that these are globally relevant (Aitkenhead and McDowell 2000; Li et al. 2017).

The comparatively high DOC yields from British rivers compared to most continental-scale data (Fig. 9) likely reflect the higher proportion of peat soil coverage (12\% versus a global mean of $3 \%$ ) as well as the comparatively high rainfall. The relatively short residence time of DOC in the short rivers of the UK, and limited influence of lakes in many catchments, also likely constrains the potential for DOC to be removed through mineralisation or flocculation and 
burial within drainage networks, when compared to many continental river systems.

\section{Conclusions}

The yield of DOC from British rivers is higher than the global mean, and higher than that of most large world rivers. To the extent that Great Britain can be considered representative of the relatively peat-rich, high-rainfall oceanic temperate zones of the Northern and Southern Hemisphere, our results suggest that the contribution of these areas to the global estimated land-ocean DOC flux may have been somewhat under-estimated. More generally, we argue that smaller river systems draining near-coastal peatland regions, including those of the humid tropics, may make a disproportionately large contribution to this flux, which risks being overlooked by global syntheses based on larger rivers.

Our estimated total riverine DOC export of $1.15 \mathrm{Tg}$ $\mathrm{C}$ year ${ }^{-1}$ from the GB land area appears to be largely natural, with spatial variations determined by intrinsic properties such as rainfall and peat cover. We did not find clear influence of agricultural or urban runoff on the total flux, although these cannot be ruled out, and they may also have affected DOM composition. On the other hand, our analysis does suggest a positive influence of forest cover on DOC export, equivalent to around $15 \%$ of the total flux, which we tentatively attribute to the effects of soil drainage following establishment of non-native conifer plantations on primarily upland soils. High-SUVA ${ }_{254}$ DOM, which is characteristic of runoff from peatland areas and susceptible to photodegradation, reaches the estuaries of many upland-influenced British rivers, whereas low-SUVA 254 , more biodegradable DOM is exported from the lowland rivers of Southern England. This contrasting composition of DOM exports from different regions may have implications for its fate and ecological impact within estuaries and shelf seas.

If all of the DOC exported from the GB land area were mineralised and degassed, this would generate a $\mathrm{CO} 2$ emission of $4.20 \mathrm{Tg} \mathrm{CO}_{2}$ year $^{-1}$, equivalent to $1 \%$ of the UK's total current anthropogenic $\mathrm{CO}_{2}$ emissions. The 'anthropogenic' forestry-related component of this flux is equivalent to $15 \%$ of current estimated net $\mathrm{C}$ uptake by growing trees in the UK. While some caution is required when directly comparing these values, our data clearly suggest that the export of DOC through British rivers is a non-trivial component of the overall natural and anthropogenic $\mathrm{C}$ cycle, and may be considered a 'leak' in the terrestrial ecosystem. Overall, our results support the growing view that land-ocean $\mathrm{C}$ fluxes are an important and dynamic component of national and global $\mathrm{C}$ budgets, and a potential indirect pathway for anthropogenic $\mathrm{CO}_{2}$ emissions. The fate of this terrestrial DOC in the marine systems remains a significant source of uncertainty in the global $\mathrm{C}$ cycle.

Acknowledgements We thank the staff at SEPA, EA and NRW for access to sampling sites and the river flow data, the staff at the NRFA for collating river flow data from each of the national agencies, and Tom Chase for his assistance with water sampling. This work was funded by the Natural Environment Research Council as part of the LOCATE project. CEH grant no: NEC05686, NOC grant no: NE/N018087/1 and BGS grant no: NEE5782NX.

Funding This work was funded by the Natural Environment Research Council as part of the LOCATE project. CEH Grant No.: NEC05686, NOC Grant No.: NE/N018087/1 and BGS Grant No.: NEE5782NX.

Availability of data and material Data will be made available through the Environmental Information Data Centre at the end of the project.

\section{Compliance with ethical standards}

Conflict of interest The authors declare that they have no competing financial or non-financial interests.

Open Access This article is licensed under a Creative Commons Attribution 4.0 International License, which permits use, sharing, adaptation, distribution and reproduction in any medium or format, as long as you give appropriate credit to the original author(s) and the source, provide a link to the Creative Commons licence, and indicate if changes were made. The images or other third party material in this article are included in the article's Creative Commons licence, unless indicated otherwise in a credit line to the material. If material is not included in the article's Creative Commons licence and your intended use is not permitted by statutory regulation or exceeds the permitted use, you will need to obtain permission directly from the copyright holder. To view a copy of this licence, visit http://creativecommons.org/licenses/by/4.0/.

\section{References}

Aitkenhead JA, McDowell WH (2000) Soil C:N ratio as a predictor of annual riverine DOC flux at local and global scales. Glob Biogeochem Cycles 14:127-138

Anderson TR, Rowe EC, Polimene L, Tipping E, Evans CD, Barry CDG, Hansell DA, Kaiser K, Kitidis V, Lapworth 
DJ, Mayor DJ, Monteith DT, Pickard AE, Sanders RJ, Spears BM, Torres R, Tye AM, Wade AJ, Waska H (2019) Unified concepts for understanding and modelling turnover of dissolved organic matter from freshwaters to the ocean: the UniDOM model. Biogeochemistry 146:105-123

Bastin J-F, Finegold Y, Garcia C, Mollicone D, Rezende M, Routh D, Zohner CM, Crowther TW (2019) The global tree restoration potential. Science 365:76-79

Baum A, Rixen T, Samiaji J (2007) Relevance of peat draining rivers in central Sumatra for the riverine input of dissolved organic carbon into the ocean. Estuar Coast Shelf Sci 73:563-570

Berggren M, del Giorgio PA (2015) Distinct patterns of microbial metabolism associated to riverine dissolved organic carbon of different source and quality. J Geophys Res Biogeosci 120:989-999

Berggren M, Klaus M, Selvam BP, Strom L, Laudon H, Jansson M, Karlsson J (2018) Quality transformation of dissolved organic carbon during water transit through lakes: contrasting controls by photochemical and biological processes. Biogeosciences 15:457-470

Brown P, Broomfield M, Cardenas L, Choudrie S, Jones L, Karagianni E, Passant N, Thistlethwaite G, Thomson A, Turtle L, Wakeling D (2019) Annual report for submission under the Framework Convention on Climate Change

Butman DE, Wilson HF, Barnes RT, Xenopoulos MA, Raymond PA (2015) Increased mobilization of aged carbon to rivers by human disturbance. Nat Geosci 8:112-116

Cauwet G (2002) DOM in coastal zones. In: Hansell DA, Carlson CA (eds) Biogeochemistry of marine dissolved organic matter. Academic Press, San Diego, pp 579-609

Ciais P, Borges AV, Abril G, Meybeck M, Folberth G, Hauglustaine D, Janssens IA (2008) The impact of lateral carbon fluxes on the European carbon balance. Biogeosciences 5:1259-1271

Ciais P, Sabine C, Bala G, Bopp L, Brovkin V, Canadell JG, Chhabra A, DeFries R, Galloway J, Heimann M, Jones CD, Le Quere C, Myneni RB, Piao S, Thornton P (2013) Carbon and other biogeochemical cycles. In: Stocker TF, Qin D, Plattner G, Tignor M, Allen SK, Boschung J, Nauels A, Xia Y, Bex V, Midgley PM (eds) Climate Change 2013: The Physical Science Basis. Contribution of Working Group 1 to the Fifth Assessment Report of the Intergovernmental Panel on Climate Change. Cambridge University Press, Cambridge

Cole JJ, Prairie YT, Caraco NF, McDowell WH, Tranvik LJ, Striegl RG, Duarte CM, Kortelainen P, Downing JA, Middelburg JJ, Melack J (2007) Plumbing the global carbon cycle: Integrating inland waters into the terrestrial carbon budget. Ecosystems 10:171-184

Committee on Climate Change (2020) Land use: Policies for a Net Zero UK.

Cory RM, Harrold KH, Neilson BT, Kling GW (2015) Controls on dissolved organic matter (DOM) degradation in a headwater stream: the influence of photochemical and hydrological conditions in determining light-limitation or substrate-limitation of photo-degradation. Biogeosciences 12:6669-6685

Dai M, Yin Z, Meng F, Liu Q, Cai W (2012) Spatial distribution of riverine DOC inputs to the ocean: an updated global synthesis. Curr Opin Environ Sustain 4:170-178
De Wit HA, Austnes K, Hylen G, Dalsgaard L (2015) A carbon balance of Norway: terrestrial and aquatic carbon fluxes. Biogeochemistry 123:147-173

Drake TW, Raymond PA, Spencer RGM (2018) Terrestrial carbon inputs to inland waters: a current synthesis of estimates and uncertainty. Limnol Oceanogr Lett 3:132-142

Evans CD, Artz R, Moxley J, Smyth M-A, Taylor EM, Archer N, Burden A, Williamson J, Donnelly D, Thomson A, Buys G, Malcolm H, Wilson D, Renou-Wilson F (2017a) Implementation of an emission inventory for UK peatlands. Report to the Department for Business, Energy and Industrial Strategy. Centre for Ecology \& Hydrology, Bangor

Evans CD, Futter MN, Moldan F, Valinia S, Frogbrook Z, Kothawala DN (2017) Variability in organic carbon reactivity across lake residence time and trophic gradients. Nat Geosci 10:832-+

Evans CD, Jones TG, Burden A, Ostle N, Zielinski P, Cooper MDA, Peacock M, Clark JM, Oulehle F, Cooper D, Freeman C (2012) Acidity controls on dissolved organic carbon mobility in organic soils. Glob Chang Biol 18:3317-3331

Evans CD, Renou-Wilson F, Strack M (2016) The role of waterborne carbon in the greenhouse gas balance of drained and re-wetted peatlands. Aquat Sci 78:573-590

Graeber D, Goyenola G, Meerhoff M, Zwirnmann E, Ovesen NB, Glendell M, Gelbrecht J, de Mello FT, GonzalezBergonzoni I, Jeppesen E, Kronvang B (2015) Interacting effects of climate and agriculture on fluvial DOM in temperate and subtropical catchments. Hydrol Earth Syst Sci 19:2377-2394

Gustard A, Bullock A, Dixon JM (1992) Low flow estimation in the United Kingdom. IH Report No. 108

Hanley KW, Wollheim WM, Salisbury J, Huntington T, Aiken G (2013) Controls on dissolved organic carbon quantity and chemical character in temperate rivers of North America. Glob Biogeochem Cycles 27:492-504

Hope D, Billett MF, Milne R, Brown TAW (1997) Exports of organic carbon in British rivers. Hydrol Process 11:325-344

Huang TH, Fu YH, Pan PY, Chen CTA (2012) Fluvial carbon fluxes in tropical rivers. Curr Opin Environ Sustain 4:162-169

Jones TG, Evans CD, Jones DL, Hill PW, Freeman C (2016) Transformations in DOC along a source to sea continuum; impacts of photo-degradation, biological processes and mixing. Aquat Sci 78:433-446

Koehler B, Broman E, Tranvik LJ (2016) Apparent quantum yield of photochemical dissolved organic carbon mineralization in lakes. Limnol Oceanogr 61:2207-2221

Koehler B, Landelius T, Weyhenmeyer GA, Machida N, Tranvik LJ (2014) Sunlight-induced carbon dioxide emissions from inland waters. Glob Biogeochem Cycles 28:696-711

Kohler SJ, Kothawala D, Futter MN, Liungman O, Tranvik L (2013) In-lake processes offset increased terrestrial inputs of dissolved organic carbon and color to lakes. PLoS ONE 8:e70598

Kritzberg ES, Ekstrom SM (2012) Increasing iron concentrations in surface waters-a factor behind brownification? Biogeosciences 9:1465-1478 
Lambert T, Bouillon S, Darchambeau F, Massicotte P, Borges AV (2016) Shift in the chemical composition of dissolved organic matter in the Congo River network. Biogeosciences 13:5405-5420

Lambert T, Bouillon S, Darchambeau F, Morana C, Roland FAE, Descy JP, Borges AV (2017) Effects of human land use on the terrestrial and aquatic sources of fluvial organic matter in a temperate river basin (The Meuse River, Belgium). Biogeochemistry 136:191-211

Lambert T, Darchambeau F, Bouillon S, Alhou B, Mbega JD, Teodoru CR, Nyoni FC, Massicotte P, Borges AV (2015) Landscape control on the spatial and temporal variability of chromophoric dissolved organic matter and dissolved organic carbon in large African Rivers. Ecosystems 18:1224-1239

Li M, Peng C, Wang M, Xue W, Zhang K, Wang K, Shi G, Zhu Q (2017) The carbon flux of global rivers: a re-evaluation of amount and spatial patterns. Ecol Ind 80:40-51

Littlewood IG, Watts CD, Custance JM (1998) Systematic application of United Kingdom river flow and quality databases for estimating annual river mass loads (1975-1994). Sci Total Environ 210:21-40

Ludwig W, Probst J-L, Kempe S (1996) Predicting the oceanic input of organic carbon by continental erosion. Glob Biogeochem Cycles 10:23-41

Massicotte P, Asmala E, Stedmon C, Markager S (2017) Global distribution of dissolved organic matter along the aquatic continuum: across rivers, lakes and oceans. Sci Total Environ 609:180-191

Menberu M, Mattila H, Tahvanainen T, Kotiaho JS, Hokkanen R, Klove B, Ronkanen A (2017) Changes in pore water quality after peatland restoration: assessment of a large scale replicated before-after-control-impact study in Finland. Water Resour Res 53:8327-8343

Meybeck M (1982) Carbon, nitrogen, and phosphorus transport by world rivers. Am J Sci 282:401-450

Monteith DT, Stoddard JL, Evans CD, de Wit HA, Forsius M, Hogasen T, Wilander A, Skjelkvale BL, Jeffries DS, Vuorenmaa J, Keller B, Kopacek J, Vesely J (2007) Dissolved organic carbon trends resulting from changes in atmospheric deposition chemistry. Nature 450:537-U539

Moody CS, Worrall F, Evans CD, Jones TG (2013) The rate of loss of dissolved organic carbon (DOC) through a catchment. J Hydrol 492:139-150

Moore S, Evans CD, Page SE, Garnett MH, Jones TG, Freeman C, Hooijer A, Wiltshire AJ, Limin SH, Gauci V (2013) Deep instability of deforested tropical peatlands revealed by fluvial organic carbon fluxes. Nature 493:660-+

Moore S, Gauci V, Evans CD, Page SE (2011) Fluvial organic carbon losses from a Bornean blackwater river. Biogeosciences 8:901-909

Morris DG, Flavin RW (1990) A digital terrain model for hydrology. In: 4th International Symposium on Spatial Data Handling, pp 250-262

Nichols JE, Peteet DM (2019) Rapid expansion of northern peatlands and doubled estimate of carbon storage. Nat Geosci 12:917-921

O’Donnell JA, Aiken GR, Swanson DK, Panda S, Butler KD, Baltensperger AP (2016) Dissolved organic matter composition of Arctic rivers: linking permafrost and parent material to riverine carbon. Glob Biogeochem Cycles 30:1811-1826

Painter SC, Lapworth DJ, Woodward EMS, Kroeger S, Evans CD, Mayor DJ, Sanders RJ (2018) Terrestrial dissolved organic matter distribution in the North Sea. Sci Total Environ 630:630-647

Pereira R, Bovolo CI, Spencer RGM, Hernes PJ, Tipping E, Veith-Hillebrand A, Pedentchouk N, Chappell NA, Parkin G, Wagner T (2014) Mobilization of optically invisible dissolved organic matter in response to rainstorm events in a tropical forest headwater river. Geophys Res Lett 41:1202-1208

R Core Team (2018) R: a language for statistical computing., R Foundation for Statistical Computing, Vienna

Raike A, Kortelainen P, Mattsson T, Thomas DN (2016) Longterm trends (1975-2014) in the concentrations and export of carbon from Finnish rivers to the Baltic Sea: organic and inorganic components compared. Aquat Sci 78:505-523

Raymond PA, Oh NH, Turner RE, Broussard W (2008) Anthropogenically enhanced fluxes of water and carbon from the Mississippi River. Nature 451:449-452

Raymond PA, Spencer RGM (2015) Riverine DOM. In: Hansell DA, Carlson CA (eds) Biogeochemistry of marine dissolved organic matter. Academic Press, Bulrlington, pp 509-533

Regnier P, Friedlingstein P, Ciais P, Mackenzie FT, Gruber N, Janssens IA, Laruelle GG, Lauerwald R, Luyssaert S, Andersson AJ, Arndt S, Arnosti C, Borges AV, Dale AW, Gallego-Sala A, Godderis Y, Goossens N, Hartmann J, Heinze C, Ilyina T, Joos F, LaRowe DE, Leifeld J, Meysman FJR, Munhoven G, Raymond PA, Spahni R, Suntharalingam P, Thullner M (2013) Anthropogenic perturbation of the carbon fluxes from land to ocean. Nat Geosci 6:597-607

Rowland CS, Morton RD, Carrasco L, McShane G, O’Neil AW, Wood CM (2017) Land Cover Map 2015 (vector, GB). NERC Environmental Information Data Centre

Scharlemann JPW, Tanner EVJ, Hiederer R, Kapos V (2014) Global soil carbon: understanding and managing the largest terrestrial carbon pool. Carbon Manag 5:81-91

Skerlep M, Steiner E, Axelsson AL, Kritzberg ES (2019) Afforestation driving long-term surface water browning. Glob Chang Biol 26:1390-1399

Spackman E (1993) Calculation and mapping of rainfall averages for 1961-90. University of Salford, Manchester

Stets EG, Striegl RG (2012) Carbon export by rivers draining the conterminous United States. Inland Waters 2:177-184

Stuart ME, Lapworth DJ (2016) Macronutrient status of UK groundwater: nitrogen, phosphorus and organic carbon. Sci Total Environ 572:1543-1560

Tranvik LJ, Downing JA, Cotner JB, Loiselle SA, Striegl RG, Ballatore TJ, Dillon P, Finlay K, Fortino K, Knoll LB, Kortelainen PL, Kutser T, Larsen S, Laurion I, Leech DM, McCallister SL, McKnight DM, Melack JM, Overholt E, Porter JA, Prairie Y, Renwick WH, Roland F, Sherman BS, Schindler DW, Sobek S, Tremblay A, Vanni MJ, Verschoor AM, von Wachenfeldt E, Weyhenmeyer GA (2009) Lakes and reservoirs as regulators of carbon cycling and climate. Limnol Oceanogr 54:2298-2314

Voss M, Dippner JW, Humborg C, Hurdler J, Korth F, Neumann T, Schewrnewski G, Venohr M (2011) History and 
scenarios of future development of Baltic Sea eutrophication. Estuar Coast Shelf Sci 92:307-322

Weishaar JL, Aiken GR, Bergamaschi BA, Fram MS, Fujii R, Mopper K (2003) Evaluation of specific ultraviolet absorbance as an indicator of the chemical composition and reactivity of dissolved organic carbon. Environ Sci Technol 37:4702-4708

Williamson J, Morton RD, Artz R, Burden A, Rowland CS, Carrasco L, O'Neil AW, Poggio L, Khomik M, Donnelly D, Evans CD (2018) The role of earth observation in an integrated framework for assessing peatland habitat condition and its impact on greenhouse gas accounting. Brain Sci 8(3): 1

Wollheim WM, Stewart RJ, Aiken GR, Butler KD, Morse NB, Salisbury J (2015) Removal of terrestrial DOC in aquatic ecosystems of a temperate river network. Geophys Res Lett 42:6671-6679

Worrall F, Davies H, Bhogal A, Lilly A, Evans M, Turner K, Burt T, Barraclough D, Smith P, Merrington G (2012) The flux of DOC from the UK - Predicting the role of soils, land use and net watershed losses. J Hydrol 448:149-160

Worrall F, Howden NJK, Burt TP, Bartlett R (2018) Declines in the dissolved organic carbon (DOC) concentration and flux from the UK. J Hydrol 556:775-789
Worrall F, Howden NJK, Burt TP, Bartlett R (2019) The importance of sewage effluent discharge in the export of dissolved organic carbon from UK rivers. Hydrol Process 33:1851-1864

Yallop AR, Clutterbuck B, Thacker J (2010) Increases in humic dissolved organic carbon export from upland peat catchments: the role of temperature, declining sulphur deposition and changes in land management. Clim Res 45:43-56

Yamashita Y, Panton A, Mahaffey C, Jaffe R (2011) Assessing the spatial and temporal variability of dissolved organic matter in Liverpool Bay using excitation-emission matrix fluorescence and parallel factor analysis. Ocean Dyn 61:569-579

Yates CA, Johnes PJ, Spencer RGM (2016) Assessing the drivers of dissolved organic matter export from two contrasting lowland catchments, U.K. Sci Total Environ 569:1330-1340

Yu ZC (2012) Northern peatland carbon stocks and dynamics: a review. Biogeosciences 9:4071-4085

Publisher's Note Springer Nature remains neutral with regard to jurisdictional claims in published maps and institutional affiliations. 